\title{
Hemodialysis Affects Phenotype and Proliferation of CD4-Positive T Lymphocytes
}

\author{
Katarzyna A. Lisowska • Alicja Dębska-Ślizień • \\ Aleksandra Jasiulewicz • Zbigniew Heleniak • \\ Ewa Bryl • Jacek M. Witkowski
}

Received: 22 July 2011 /Accepted: 27 September 2011 / Published online: 13 October 2011

(C) The Author(s) 2011. This article is published with open access at Springerlink.com

\begin{abstract}
CD}^{+} \mathrm{T}$ lymphocytes of patients with chronic kidney disease (CKD) are characterized by reduced levels of crucial surface antigens and changes in the cell cycle parameters. Recombinant human erythropoietin (rhEPO) normalizes their altered phenotype and proliferative capacity. Mechanisms leading to the deficient responses of $\mathrm{T}$ lymphocytes are still not clear but it is postulated that immunological changes are deepened by hemodialysis (HD). Study of activation parameters of $\mathrm{CD}^{+} \mathrm{T}$ lymphocytes in hemodialyzed and predialysis CKD patients could bring insight into this problem. Two groups of patients, treated conservatively (predialysis, PD) and hemodialyzed (HD), as well as healthy controls, were included into the study; neither had received rhEPO. Proportions of main $\mathrm{CD}^{+} \mathrm{CD} 28^{+}, \mathrm{CD} 4^{+} \mathrm{CD} 25^{+}, \mathrm{CD} 4^{+} \mathrm{CD} 69^{+}, \mathrm{CD} 4^{+} \mathrm{CD} 95^{+}$, and $\mathrm{CD} 4^{+} \mathrm{HLA}-\mathrm{DR}^{+}$lymphocyte subpopulations and proliferation kinetic parameters were measured with flow cytometry, both ex vivo and in vitro. No differences were seen in the proportions of main $\mathrm{CD}^{+}$lymphocyte subpopulations $\left(\mathrm{CD} 4^{+} \mathrm{CD} 28^{+}, \mathrm{CD}^{+} \mathrm{CD} 25^{+}, \mathrm{CD} 4^{+} \mathrm{HLA}-\right.$ $\mathrm{DR}^{+}, \mathrm{CD} 4^{+} \mathrm{CD} 69^{+}, \mathrm{CD} 4^{+} \mathrm{CD} 95^{+}$) between all examined groups ex vivo. $\mathrm{CD}^{+} \mathrm{T}$ lymphocytes of $\mathrm{HD}$ patients exhibited significantly decreased expression of costimulatory molecule CD28 and activation markers CD25 and CD69 after stimulation in vitro when compared with
\end{abstract}

K. A. Lisowska $(\bowtie) \cdot$ A. Jasiulewicz $\cdot$ E. Bryl $\cdot$ J. M. Witkowski Department of Pathophysiology, Medical University of Gdańsk, Dębinki 7,

80-211 Gdańsk, Poland

e-mail: katlis@gumed.edu.pl

A. Dębska-Ślizień · Z. Heleniak

Department of Nephrology, Transplantology and Internal

Diseases, Medical University of Gdańsk,

Gdańsk, Poland
PD patients and healthy controls. HD patients showed also decreased percentage of $\mathrm{CD} 4{ }^{+} \mathrm{CD} 28^{+}$lymphocytes proliferating in vitro; these cells presented decreased numbers of finished divisions after $72 \mathrm{~h}$ of stimulation in vitro and had longer $\mathrm{G} 0 \rightarrow \mathrm{G} 1$ time when compared to healthy controls. $\mathrm{CD}^{+} \mathrm{T}$ lymphocytes of PD patients and healthy controls were characterized by similar cell cycle parameters. Our study shows that repeated hemodialysis procedure influences phenotype and proliferation parameters of $\mathrm{CD}^{+} \mathrm{T}$ lymphocytes.

Keywords $\mathrm{CD} 4{ }^{+} \mathrm{T}$ lymphocytes $\cdot$ antigens $\cdot$ proliferation . hemodialysis

\section{Introduction}

Chronic kidney disease (CKD) is characterized by slow loss of kidney function over a period of years. The goal of CKD treatment is to delay progression of the disease, but when the patient reaches stage 5 of CKD (end-stage renal diseaseESRD), renal replacement therapy (dialysis or kidney transplantation) is necessary [1]. Apart from uremia, electrolyte disturbances, hypertension, and anemia, CKD patients also present inappropriate parameters of nonspecific and specific immunity. The most frequent findings include abnormally high activity of monocytes based on production of proinflammatory cytokines: tumor necrosis factor-alpha (TNF- $\alpha$ ), interleukin (IL)-1, and IL-6 [2, 3]. It is also reported that $\mathrm{CKD}$ patients present decreased percentages of peripheral $\mathrm{T}$ lymphocytes, both $\mathrm{CD} 4^{+}$and $\mathrm{CD} 8^{+}$cells, and $\mathrm{B}$ lymphocytes in the blood $[4,5]$. Furthermore, decreased IL-2 and interferon gamma production as an answer to stimulation are observed in CKD patients [6,7]. A detailed study revealed that stimulated $\mathrm{CD}^{+} \mathrm{T}$ lymphocytes of $\mathrm{CKD}$ 
patients present decreased expression of antigens involved in T lymphocyte activation: major co-stimulatory CD28 antigen and early activation antigen CD69 [7]. The decreased levels of these antigens, especially CD28, could be one of the reasons for deficient reactions of $\mathrm{T}$ lymphocytes. $\mathrm{CD} 28$ regulates IL-2 production on the transcriptional level [8], and its lower expression explains reduced levels of IL-2 in response to mitogenic stimulation in CKD patients. Also, fewer $\mathrm{CD} 4{ }^{+} \mathrm{CD} 28^{+}$lymphocytes of $\mathrm{CKD}$ patients proliferate in vitro, and these cells require more time to enter the first phase (G1) of the cell cycle [7]. $\mathrm{CD}^{+} \mathrm{T}$ lymphocytes are involved in both cell-mediated and humoral immune responses; consequently, their changed phenotype and disturbances in proliferation kinetics lead to impaired immunity observed as decreased immunoglobulin production by $\mathrm{B}$ lymphocytes resulting in poor response of CKD patients to vaccination and increased susceptibility to infections [9].

There is still little known about the mechanisms that cause immunological deficiency in $\mathrm{CKD}$, but it seems that these changes are deepened mainly by hemodialysis (HD) procedures. At least, all the aforementioned disturbances in cellular and humoral immunity were described in HD patients. Dialytic membrane incompatibility, bacterial contamination of dialyzer, and vascular access are the main reasons for inflammatory response in CKD patients. Direct contact of peripheral blood mononuclear cells (PBMC) with artificial membrane initiates abnormal production of proinflammatory cytokines by monocytes [10]. Furthermore, the HD procedure induces also apoptosis of $\mathrm{T}$ lymphocytes, which leads to $\mathrm{T}$ cell lymphopenia observed in patients [11]. However, it is not clear if changes in phenotype, cytokine production, and proliferation of $\mathrm{T}$ lymphocytes result only from repeated hemodialysis procedure or are connected with CKD progression, since there are no detailed studies comparing these parameters in hemodialyzed and predialysis CKD patients. Most of the articles focus only on numbers or proportions of lymphocytes in the blood of patients. Meanwhile, surface antigens of lymphocytes and their proliferation kinetics are the key parameters crucial for cell-mediated and humoral responses. Therefore, we have chosen for our study the molecules crucial for the activity of $\mathrm{CD}^{+} \mathrm{T}$ lymphocytes (CD28 antigen-costimulatory molecule important for antigen presentation; activation markers-CD69 (early), CD25, CD95 (middle), HLA-DR (late)) and analyzed their expression along with proliferation parameters of $\mathrm{T} \mathrm{CD}^{+}$lymphocytes in hemodialyzed and predialysis patients.

\section{Patients and Methods}

Patients The study groups consisted of 25 CKD patients (mean age $60.32 \pm 17.92$ years) and 14 healthy individuals (mean age $53.14 \pm 11.55$ years). The 15 patients underwent 5 -h sessions of hemodialysis three times a week. The average time of hemodialysis was $1.18 \pm 0.57$ months with the shortest time of 2 weeks and the longest of 2 months. Ninety-five percent of examined CKD patients were CMV seropositive but none of them presented symptoms of an active infectious process during the study. Ten patients were treated conservatively (predialysis patients). The study has been approved by the Ethical Committee of the Medical University of Gdańsk. The main features of patients and controls are presented in Table I. Mean hemoglobin was significantly decreased in all groups of patients with CKD when compared to healthy control. All patients had stage 5 of CKD (ESRD) (Table I).

Stainings and Flow Cytometry Analysis of Antigens of $C D 4^{+}$Lymphocytes Thirty milliliters of venous peripheral blood was collected in tubes containing EDTA as the anti-coagulant from each $\mathrm{HD}$ patient before the HD session and from patients treated conservatively and healthy volunteers. Five milliliters of blood was designed for morphology. Samples of $50 \mu$ per tube blood were transferred for staining with monoclonal antibodies ex vivo and red blood cell lysis. Blood cells were stained with FITC-conjugated anti-CD3, RPE-Cy5-conjugated anti-CD4 (DAKO, Denmark), PE-conjugated anti-CD28, PE-conjugated anti-CD69 (BD-Pharmigen, USA), PEconjugated anti-CD25 (DAKO, Denmark), PEconjugated anti-CD95, and PE-conjugated anti-HLA-DR (BD-Pharmigen) antibodies and incubated for $30 \mathrm{~min}$ at $4^{\circ} \mathrm{C}$.

After antibody staining, red blood cells were lysed with buffer containing $0.8 \% \mathrm{NH}_{4} \mathrm{Cl}$ and $0.1 \% \mathrm{KHCO}_{3}$. Finally, cells were resuspended in $200 \mu \mathrm{l}$ of PBS buffer
Table I Basic characteristics of patients and controls

${ }^{*} p<0.05$ vs. control group, $t$ test for independent groups

\begin{tabular}{llll}
\hline & Predialysis patients & Hemodialyzed patients & Control \\
\hline Number & 10 & 15 & 14 \\
Age $($ years $)$ & $57.66 \pm 19.28$ & $62.15 \pm 17.46$ & $53.14 \pm 11.55$ \\
Sex $(\mathrm{M} / \mathrm{F})$ & $7 / 3$ & $11 / 4$ & $9 / 5$ \\
GFR $\left(\mathrm{min} / \mathrm{ml} / 1.73 \mathrm{~m}^{2}\right)$ & $13.10 \pm 5.53$ & $10.68 \pm 3.27$ & $>60$ \\
Hemoglobin $(\mathrm{g} / \mathrm{dl})$ & $10.51 \pm 1.33^{*}$ & $9.86 \pm 1.03^{*}$ & $14.04 \pm 0.73$
\end{tabular}


Fig. 1 Flow cytometric analysis of subpopulations and proliferation of $\mathrm{T}$ lymphocytes ex vivo and in vitro. Whole blood cells were stained with monoclonal antibodies against $\mathrm{CD} 3, \mathrm{CD} 4$, and CD28 antigens. First, T lymphocytes were selected on the basis of their forward and side scatter characteristics (a) and CD3 expression (b). Finally, $\mathrm{CD}^{+} \mathrm{T}$ lymphocytes were visualized in dot-plot showing CD4 and CD28 (or other antigen) on the $x$ - and $y$-axes, respectively (c). Meanwhile, proliferating $\mathrm{T}$ lymphocytes (stained with CFSE as described in "Patients and Methods") were also selected on the basis of their forward and side scatter characteristics (d). Next, the subpopulation of lymphocytes of interest (for example $\mathrm{CD} 4^{+} \mathrm{CD} 28^{+}$cells) was gated (e) and their divisions were shown in histogram (f)
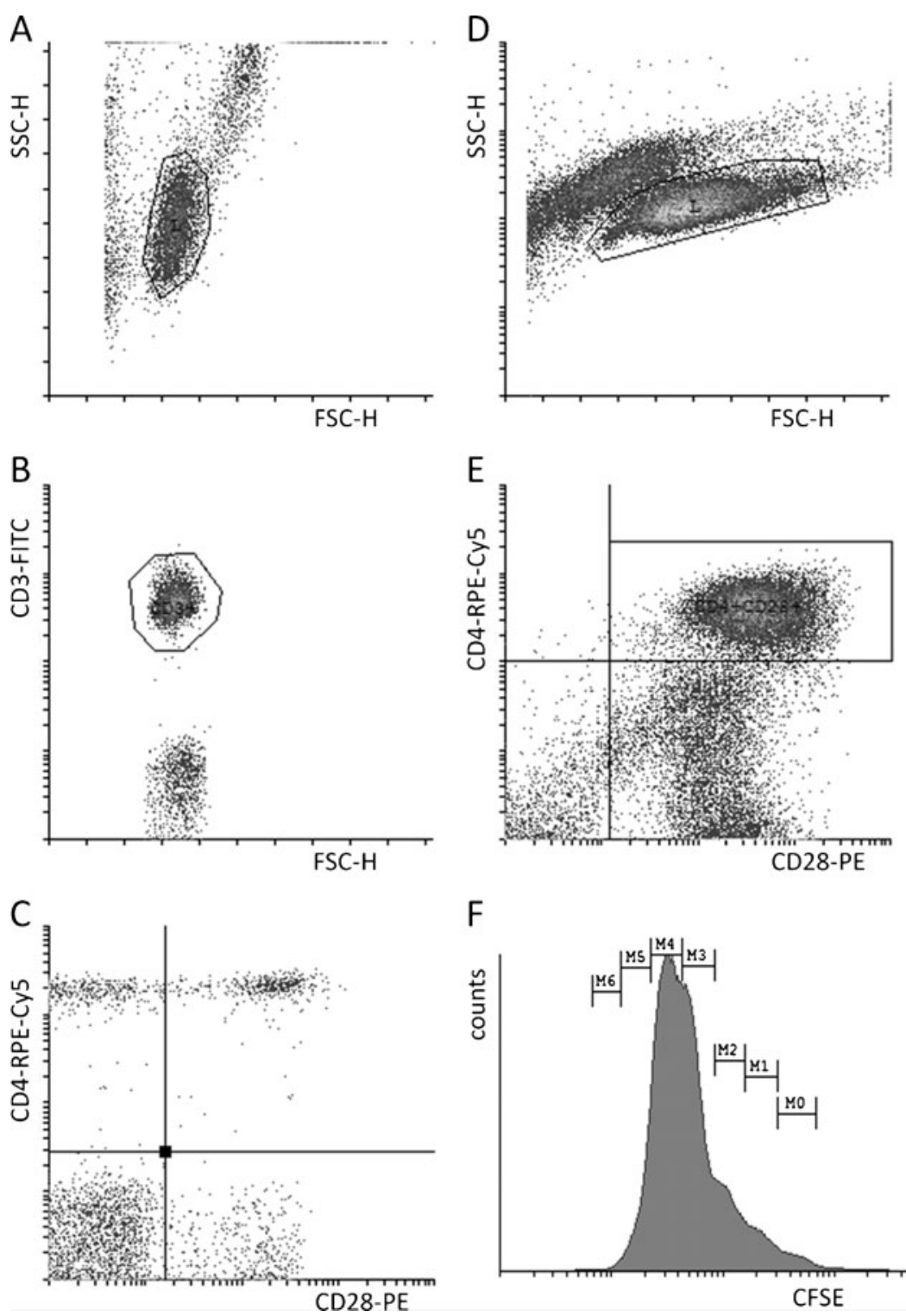

$\mathrm{F}$

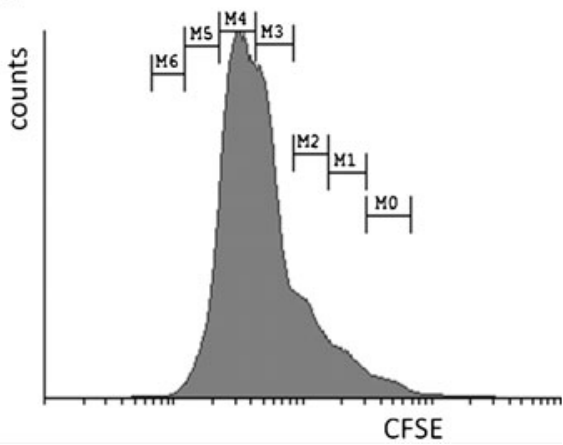

for final flow cytometric analysis. Twenty milliliters of venous blood was designed for PBMC isolation by centrifugation on Histopaque ${ }^{\mathrm{TM}}$ gradient (Sigma Chemical Co., USA).

PBMC In Vitro Stimulation and Dividing Cell Tracking The dividing cell tracking method used to examine differences in proliferation rate and the percentage of dividing cells were based on Hasbold's method [12] and modified using the method of Witkowski et al. [13]. The advantage of this method allows to stimulate the peripheral blood mononuclear cells without their purification before and to analyze the different subpopulations of dividing cells by staining with different monoclonal antibodies and using flow cytometry. The comparison between different subpopulations from one person is very valuable because the stimulation conditions are the same; therefore, the observed differences in kinetics are dependent on cell type, not on different stimulation conditions.

Twelve million of PBMC were stained with $3 \mu \mathrm{M}$ CFSE (Sigma Chemical Co.) for $15 \mathrm{~min}$ in the dark at $37^{\circ} \mathrm{C}$ and washed one time with complete medium supplemented with $0.5 \%$ FBS and two times with complete medium. Then cells were stimulated with immobilized anti-CD3 antibody (250 ng per 2 million cells in $2 \mathrm{ml}$ of complete medium) and incubated for 5 days at $37^{\circ} \mathrm{C}, 5 \% \mathrm{CO}_{2}$. The same conditions were applied to the unstimulated PBMC as negative control. Stimulated and unstimulated cells were collected after 72 and $120 \mathrm{~h}$ and stained with RPE-Cy5conjugated anti-CD4 (DAKO), PE-conjugated anti-CD28, PE-conjugated anti-CD69 (BD-Pharmigen), and PEconjugated anti-CD25 (DAKO) antibodies for $30 \mathrm{~min}$ at 

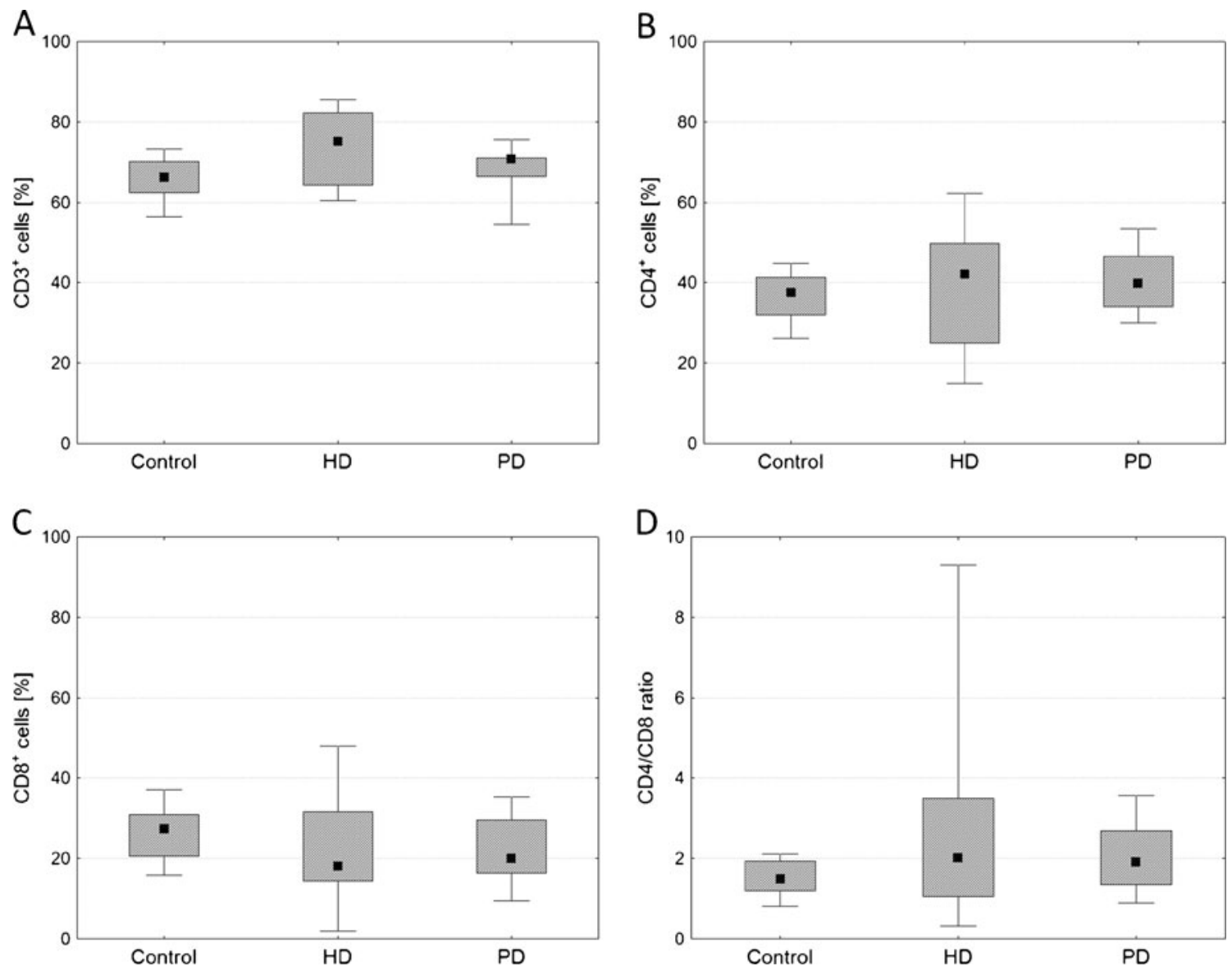

Fig. 2 Comparison of populations of main $\mathrm{T}$ lymphocytes ex vivo. Graphs show percentages of main populations: $\mathrm{CD}^{+}(\mathbf{a}), \mathrm{CD}^{+}(\mathbf{b})$, and $\mathrm{CD}^{+}$(c) as well as $\mathrm{CD} 4 / \mathrm{CD} 8$ ratio (d) in all examined groupshealthy controls (Control), hemodialyzed patients $(H D)$, and predialysis

$4^{\circ} \mathrm{C}$. After washing, cells were resuspended in $200 \mu \mathrm{l}$ of PBS buffer for flow cytometric analysis performed directly after sample preparation.
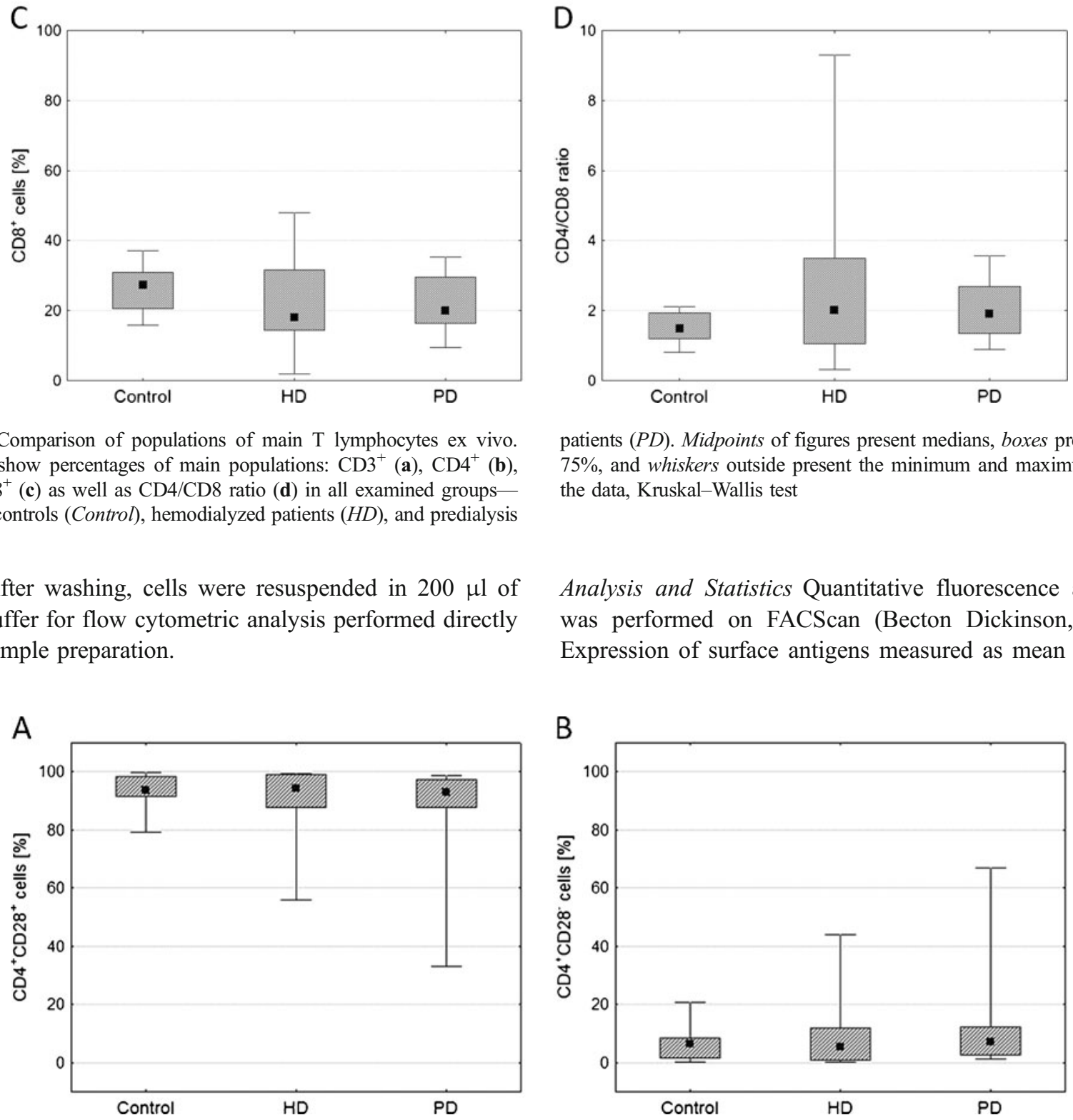

patients $(P D)$. Midpoints of figures present medians, boxes present 25 $75 \%$, and whiskers outside present the minimum and maximum of all the data, Kruskal-Wallis test

Analysis and Statistics Quantitative fluorescence analysis was performed on FACScan (Becton Dickinson, USA). Expression of surface antigens measured as mean fluores-

\section{B}

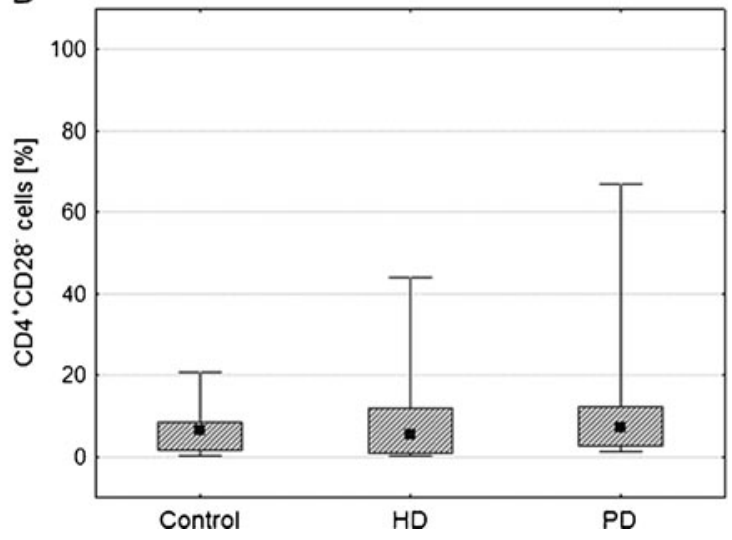

Fig. 3 Comparison of $\mathrm{CD} 4^{+} \mathrm{CD} 28^{+}$and $\mathrm{CD} 4^{+} \mathrm{CD} 28^{-}$of subpopulations of T lymphocytes ex vivo. Graphs demonstrate the percentages of $\mathrm{CD} 4^{+} \mathrm{CD} 28^{+}$(a) and $\mathrm{CD}^{+} \mathrm{CD} 28^{-}$(b) cells in all examined groups.

Midpoints of figures present medians, boxes present $25-75 \%$, and whiskers outside present the minimum and maximum of all the data, Kruskal-Wallis test 

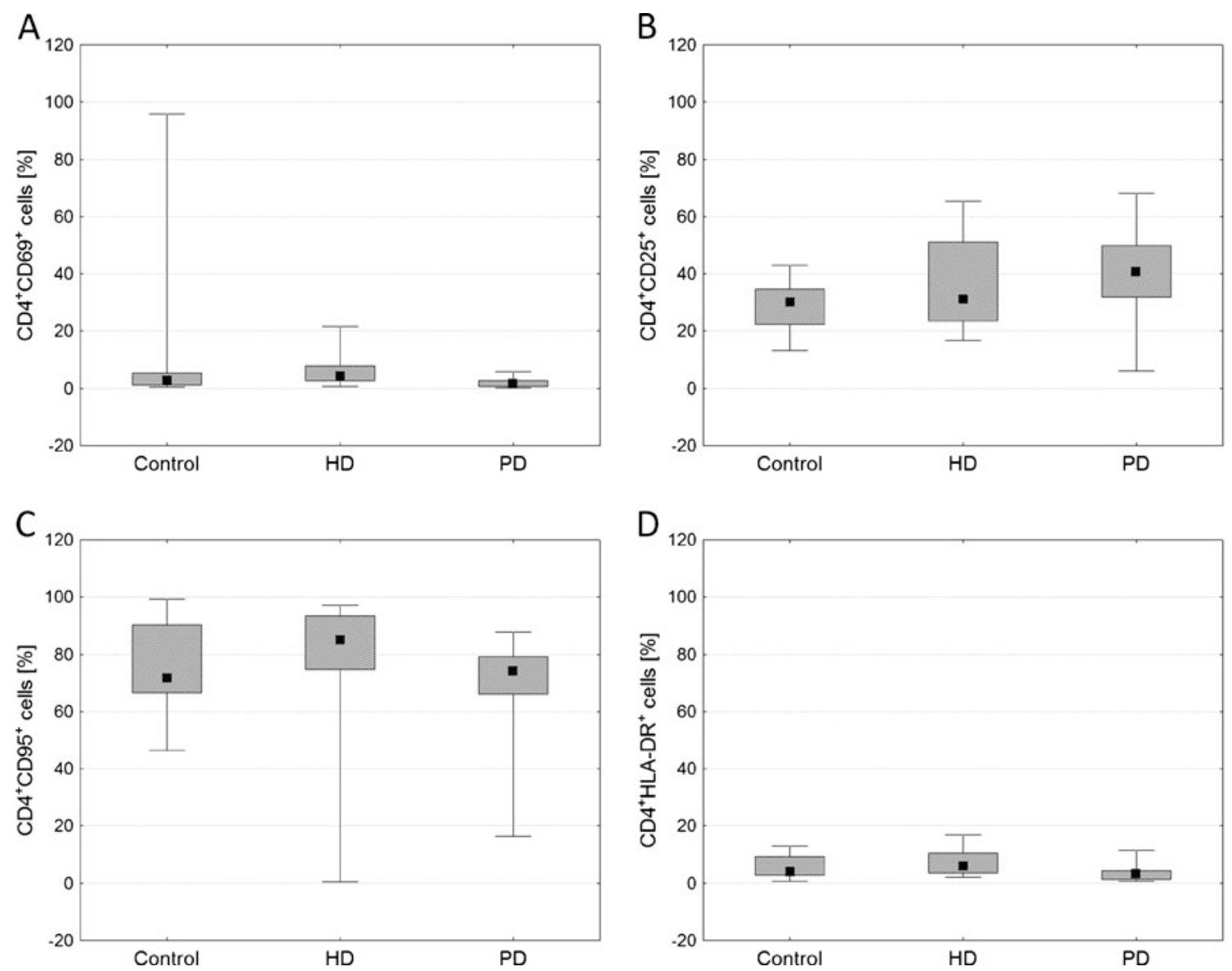

Fig. 4 Comparison of subpopulations of main active $\mathrm{CD} 4^{+} \mathrm{T}$ lymphocytes ex vivo. Graphs demonstrate the percentages of $\mathrm{CD} 4^{+} \mathrm{CD} 69^{+}$(a), $\mathrm{CD}^{+} \mathrm{CD} 25^{+}$(b), $\mathrm{CD}^{+} \mathrm{CD} 95^{+}$(c), and $\mathrm{CD} 4{ }^{+} \mathrm{HLA}-$

$\mathrm{DR}^{+}$(d) cells in all examined groups. Midpoints of figures present medians, boxes present $25-75 \%$, and whiskers outside present the minimum and maximum of all the data, Kruskal-Wallis test

cence intensity (MFI) and the percentage of $\mathrm{CD}^{+} \mathrm{T}$ lymphocytes were analyzed with the Cyflogic, version 1.2.1 (C) Perttu Terho and (C) CyFlo Ltd).

Gating strategy: Ex vivo, T lymphocytes were selected on the basis of their forward and side scatter characteristics and $\mathrm{CD} 3$ expression (Fig. 1). Isotype control (MultiMix ${ }^{\mathrm{TM}}$ Triple-Colour Control Reagent, DAKO) was used to determine the positive subpopulation of $\mathrm{CD}^{+} \mathrm{T}$ lymphocytes expressing CD28, CD69, CD25, CD95, or HLA-DR antigen. The percentage of positive $\mathrm{T}$ cells was calculated as the percentage of $\mathrm{CD}^{+} \mathrm{T}$ lymphocytes.

Proliferating $\mathrm{T}$ lymphocytes were also selected on the basis of their forward and side scatter characteristics (Fig. 1d). Next, the population of lymphocytes of interest was gated (Fig. 1e) and their divisions were shown in histogram (Fig. 1f). Calculation of cell cycle kinetics (G0 $\rightarrow$ G1 time, cell cycle duration, number of divisions per one cell, and number of finished divisions) of $\mathrm{CD} 4{ }^{+} \mathrm{CD} 28^{+}$and $\mathrm{CD} 4^{+} \mathrm{CD} 28^{-}$cells was performed according to the Witkowski protocol [13].

Statistical analysis was done using the computer program Statistica, version 8 (StatSoft, Poland). The significance tests were chosen according to the data distribution (as indicated in the "Results"). Due to irregularly distributed variances, appropriate nonparametric tests were applied. The level of significance in all was $p \leq 0.05$.

\section{Results}

Composition of Subpopulations of Main T Lymphocytes Ex Vivo No changes were seen in the percentage of $\mathrm{T}$ lymphocytes $\left(\mathrm{CD} 3^{+}\right.$cells) between PD patients, HD patients, and healthy controls ex vivo (Fig. 2a). Also, we did not observe any differences in proportions of $\mathrm{CD} 4^{+}$and $\mathrm{CD} 8^{+} \mathrm{T}$ lymphocytes as well as in $\mathrm{CD} 4 / \mathrm{CD} 8$ ratio in all examined groups (Fig. 2b-d). There was no difference in the proportions of $\mathrm{CD} 4^{+} \mathrm{CD} 28^{+} / \mathrm{CD} 4^{+} \mathrm{CD} 28^{-}$lymphocytes in all examined groups (Fig. 3). The percentages of main active 

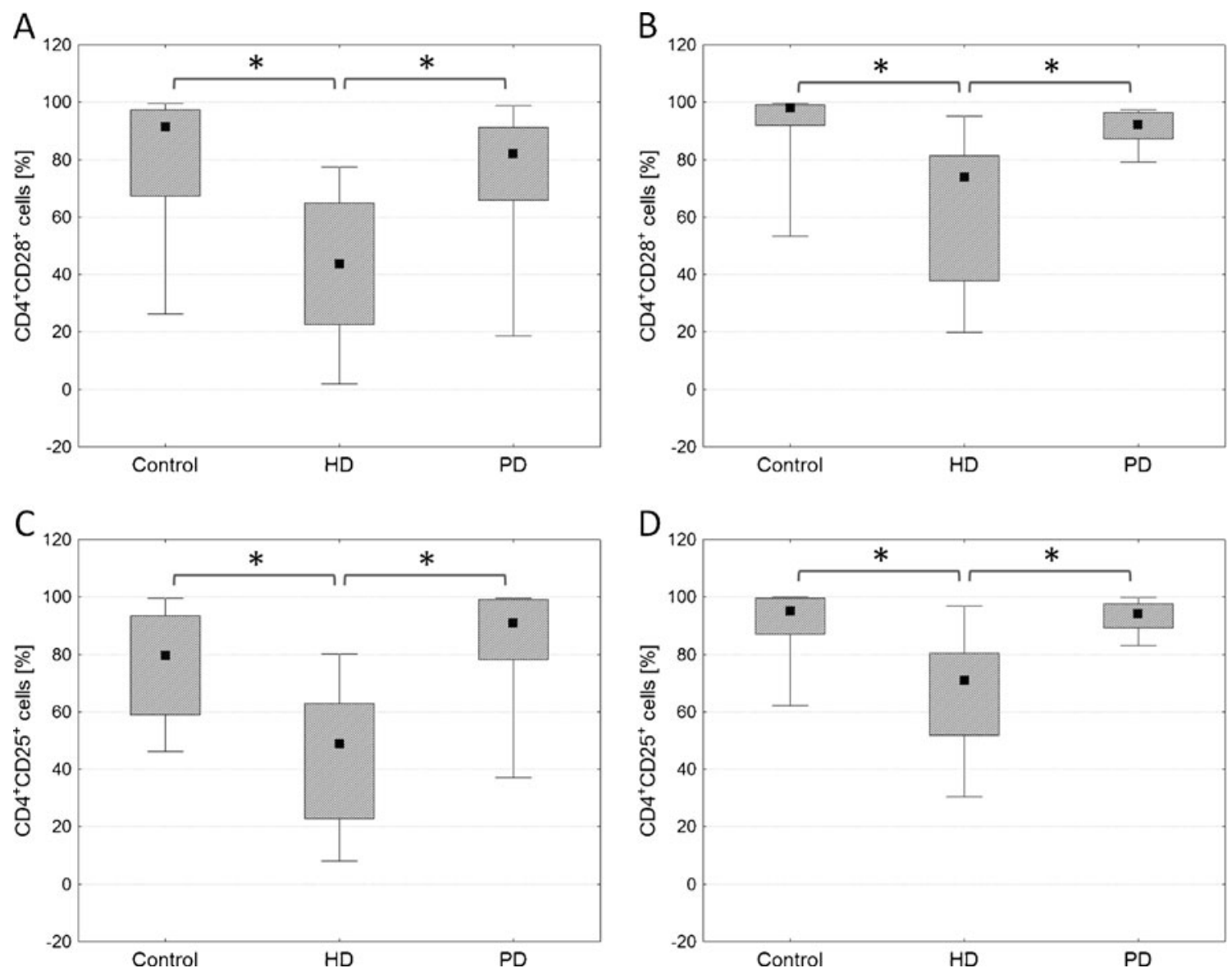

Fig. 5 Proportions of $\mathrm{CD} 4^{+} \mathrm{CD} 28^{+}$and $\mathrm{CD} 4^{+} \mathrm{CD} 25^{+} \mathrm{T}$ lymphocytes in vitro. Graphs present the percentages of $\mathrm{CD} 4^{+} \mathrm{CD} 28^{+}$and $\mathrm{CD} 4^{+} \mathrm{CD} 25^{+}$ cells after $72 \mathrm{~h}(\mathbf{a}, \mathbf{c})$ and $120 \mathrm{~h}(\mathbf{b}, \mathbf{d})$ of stimulation with anti-CD3

$\mathrm{CD}^{+} \mathrm{T}$ lymphocyte subpopulations, that is, $\mathrm{CD} 4^{+} \mathrm{CD} 25^{+}$, $\mathrm{CD} 4^{+} \mathrm{HLA}_{-\mathrm{DR}}{ }^{+}, \mathrm{CD} 4^{+} \mathrm{CD} 69^{+}$, or $\mathrm{CD} 4^{+} \mathrm{CD} 95^{+}$cells, were also at similar level in patients and healthy controls (Fig. 4).

In Vitro Studies of Subpopulations of Main $\mathrm{CD}^{+} \mathrm{T}$ Lymphocytes and Their Antigens The percentages of $\mathrm{CD} 4{ }^{+} \mathrm{CD} 28^{+}$and $\mathrm{CD} 4{ }^{+} \mathrm{CD} 25^{+} \mathrm{T}$ lymphocytes of $\mathrm{HD}$ patients were significantly decreased after 72 and $120 \mathrm{~h}$ of stimulation with anti-CD3 antibody when compared to predialysis patients and healthy controls (Fig. 5).

The major findings of the study were related to changes in the expression of CD28, CD25, and CD69 antigens on $\mathrm{CD}^{+} \mathrm{T}$ lymphocytes measured as MFI. Stimulated $\mathrm{CD} 4^{+} \mathrm{T}$ lymphocytes of HD patients presented decreased expression of co-stimulatory molecule CD28 when compared to predialysis patients and healthy controls (Fig. 6a, b). The expression of middle activation antigen CD25 (Fig. 6c, d) and early activation antigen CD69 (Fig. 6e, f) was also lower in HD patients as compared to the other two examined groups. The group of HD patients was characterized both by a lower percentage of cells with co-stimulatory and

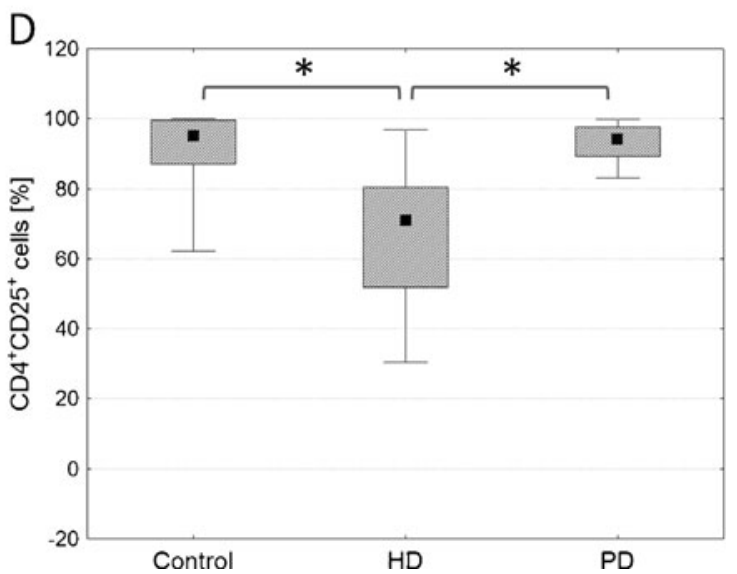

antibody in examined groups. Midpoints of figures present medians, boxes present $25-75 \%$, and whiskers outside present the minimum and maximum of all the data, ${ }^{*} p<0.05$, Kruskal-Wallis test

activation antigens and by a reduced level of these antigens on a single cell. In contrast to HD patients, $\mathrm{CD}^{+} \mathrm{T}$ lymphocytes obtained from PD patients presented levels of CD28, CD25, and CD69 similar to those observed in healthy controls.

In Vitro Studies of the Proliferation of $\mathrm{CD}^{+} \mathrm{CD} 28^{+}$and $C D 4^{+} C D 28^{-}$T Lymphocytes HD patients showed a significantly decreased percentage of $\mathrm{CD} 4^{+} \mathrm{CD} 28^{+}$lymphocytes proliferating after stimulation with the anti-CD3 antibody (Fig. 7a, b) when compared to PD patients and healthy controls. The duration of cell cycle of $\mathrm{CD} 4^{+} \mathrm{CD} 28^{+}$cells was similar in all examined groups (Fig. 7c), while the calculated period of time required by these cells to enter the G1 phase (the $\mathrm{G} 0 \rightarrow \mathrm{G} 1$ time) was longer in HD patients compared to healthy controls (Fig. 7d).

The general number of divisions of proliferating $\mathrm{CD} 4{ }^{+} \mathrm{CD} 28^{+} \mathrm{T}$ lymphocytes did not vary between all examined groups (Fig. 8a), but the number of divisions per one cell and the number of finished divisions were significantly reduced in HD patients when compared with healthy controls after $72 \mathrm{~h}$ of stimulation (Fig. 8b, c). 
$A_{800}$

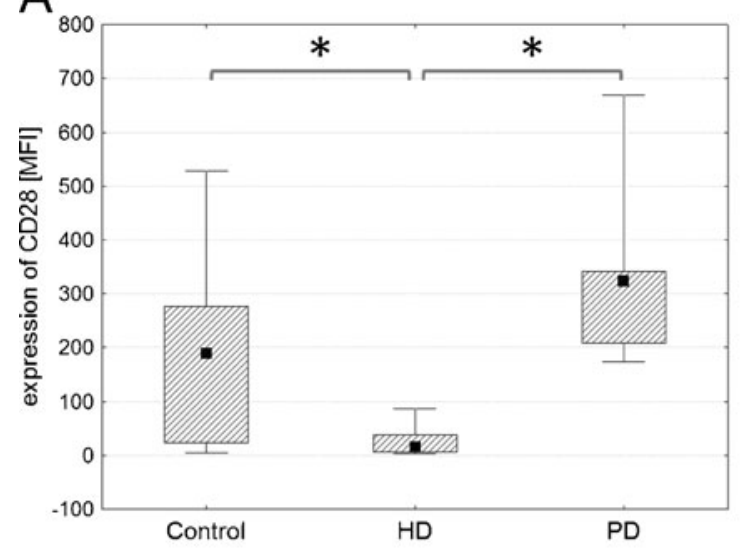

C

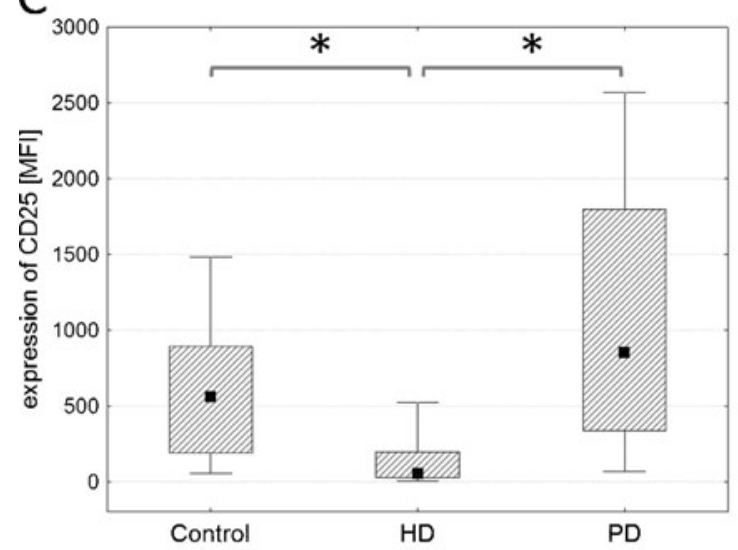

$E$

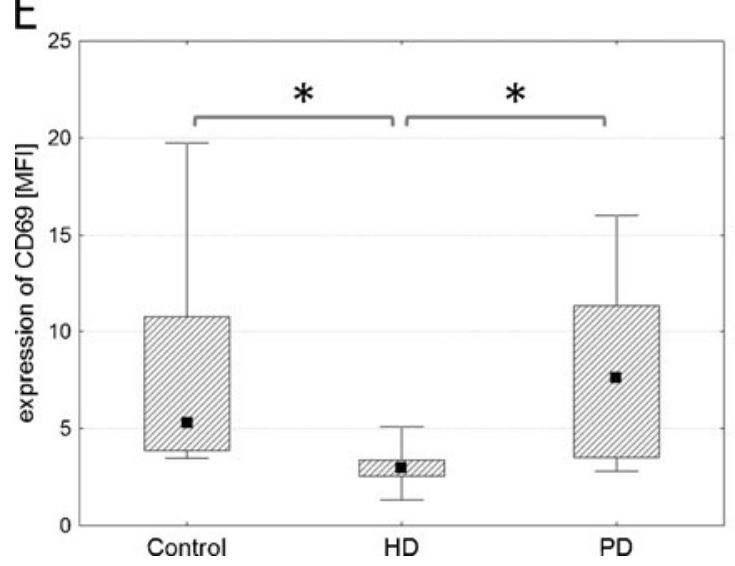

Fig. 6 Changes in the expression of CD28, CD69, and CD25 antigens on $\mathrm{CD}^{+} \mathrm{T}$ lymphocytes in vitro. Graphs show the expression of CD28, CD69, and CD25 antigens on $\mathrm{CD}^{+} \mathrm{T}$ lymphocytes after $72 \mathrm{~h}(\mathbf{a}, \mathbf{c}, \mathbf{e})$ and $120 \mathrm{~h}(\mathbf{b}, \mathbf{d}, \mathbf{f})$ of stimulation

Moreover, a decreased number of divisions per one cell was positively correlated with a decreased percentage of proliferating $\mathrm{CD}^{+} \mathrm{CD} 28^{+}$lymphocytes (Fig. 8d) and negatively correlated with longer $\mathrm{G} 0 \rightarrow \mathrm{G} 1$ time (Fig. 8e) in that group of patients. Also, a decreased number of
B

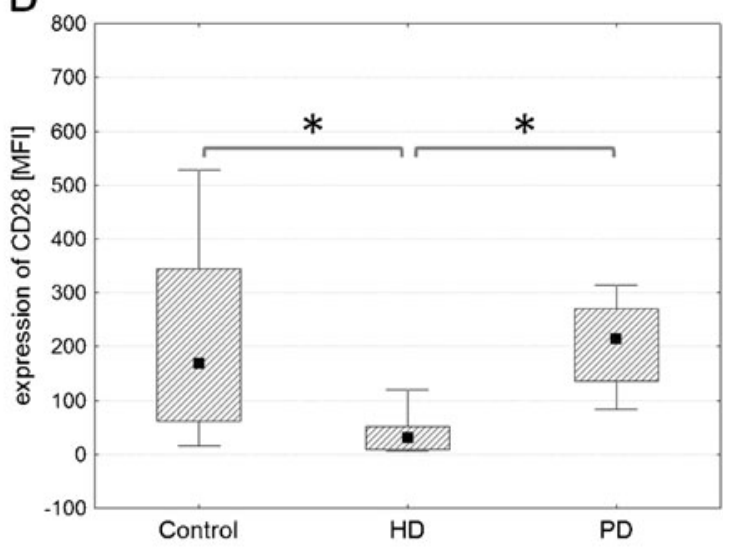

D

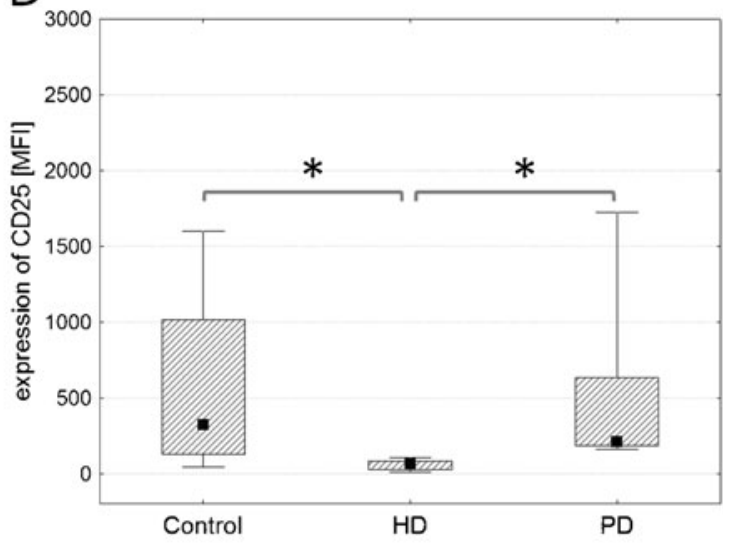

$\mathrm{F}$

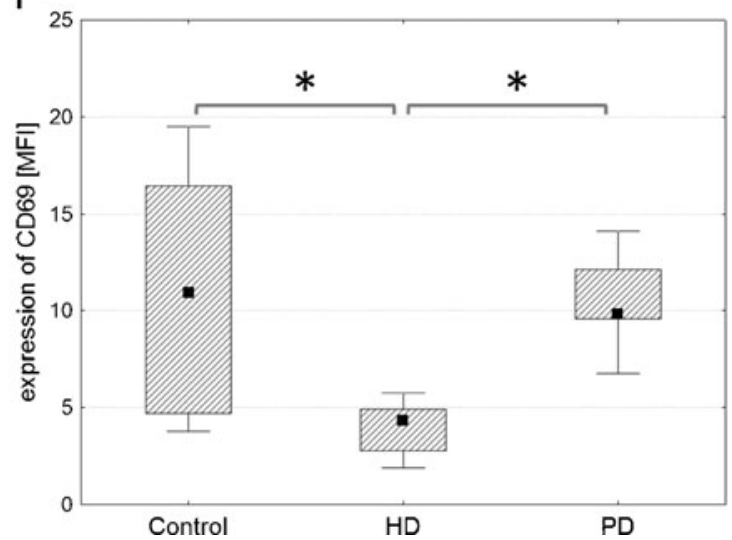

with anti-CD3 antibody in all examined groups. Midpoints of figures present medians, boxes present $25-75 \%$, and whiskers outside present the minimum and maximum of all the data, ${ }^{*} p<0.05$, Kruskal-Wallis test. MFI mean fluorescence intensity

finished divisions was negatively correlated with longer G0 $\rightarrow$ G1 time (Fig. 8f).

No changes were seen in the percentage of proliferating $\mathrm{CD} 4^{+} \mathrm{CD} 28^{-} \mathrm{T}$ lymphocytes between HD and PD patients and healthy controls (Fig. 9a). Also, the general number of 

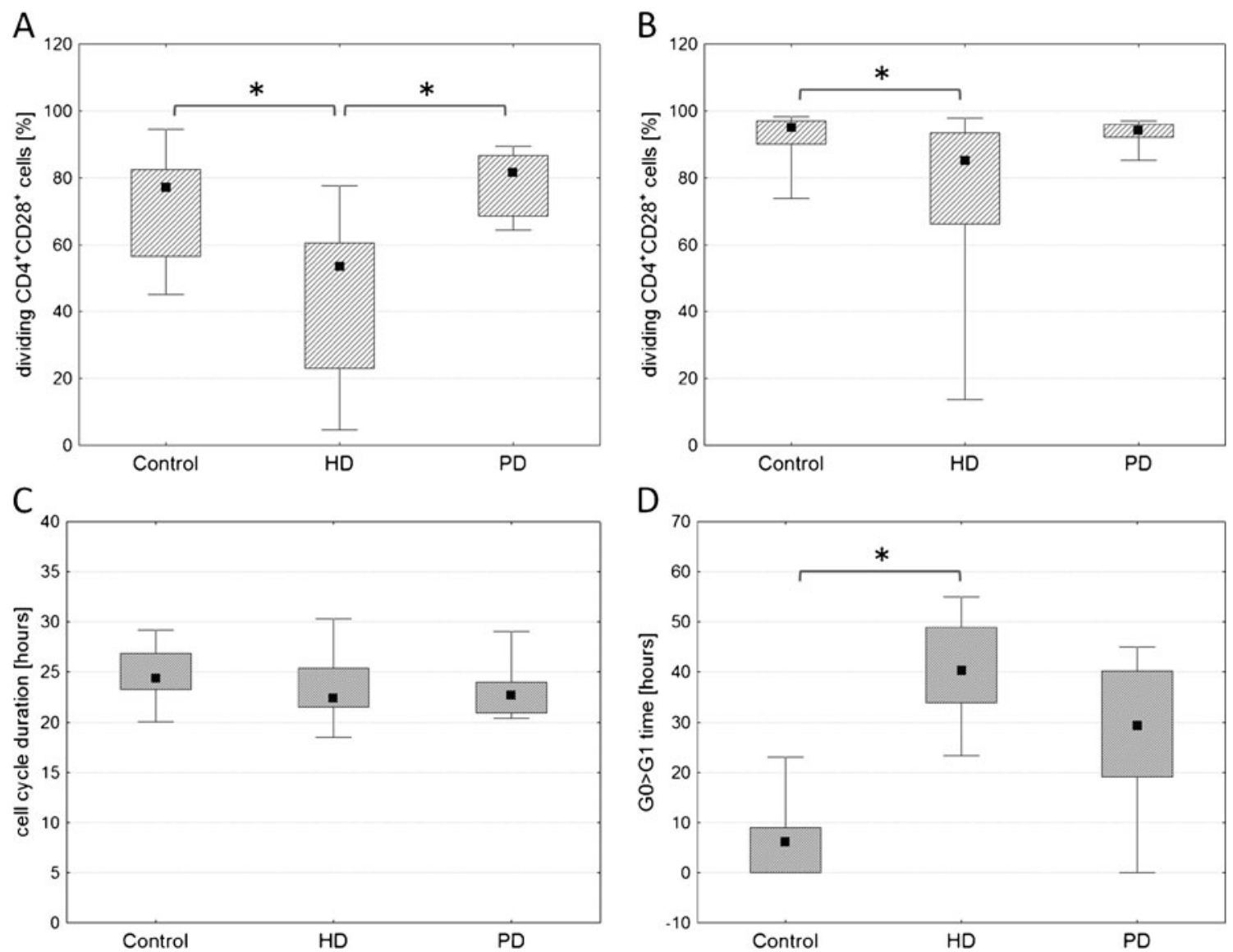

Fig. 7 Changes in main cell cycle parameters of $\mathrm{CD}^{+} \mathrm{CD} 28^{+} \mathrm{T}$ lymphocytes. Graphs present the percentage of proliferating $\mathrm{CD} 4^{+} \mathrm{CD} 28^{+}$cells after $72 \mathrm{~h}$ (a) and $120 \mathrm{~h}$ (b) of stimulation with anti-CD3 antibody, cell cycle duration (c), and time between phase G0

divisions or number of divisions per one cell did not vary between all examined groups (Fig. 9b, c).

\section{Discussion}

Immunological response mediated by $\mathrm{T}$ lymphocytes is known to be weakened in CKD patients. The influence of hemodialysis on immune response is intensively discussed and brings many contradictory information. The majority of the studies show that the numbers of $\mathrm{CD}^{+}, \mathrm{CD}^{+}$, and $\mathrm{CD} 8^{+}$cells are decreased in HD patients and postulate that the HD procedure induces apoptosis of T lymphocytes [11, 14]. Our previous studies showed that HD patients demonstrate disturbances in subpopulations of activated $\mathrm{CD}^{+} \mathrm{T}$ lymphocytes ex vivo, presented by significantly higher percentages of $\mathrm{CD} 4^{+} \mathrm{CD} 95^{+}$and $\mathrm{CD} 4^{+} \mathrm{HLA}-\mathrm{DR}^{+}$ and a lower percentage of $\mathrm{CD}^{+} \mathrm{CD} 69^{+}$cells [7]. Also, $\mathrm{CD}^{+}{ }^{+} \mathrm{T}$ lymphocytes of HD patients after stimulation with anti-CD3 antibody exhibit decreased expression of antigens and G1 (d) in examined groups. Midpoints of figures present medians, boxes present $25-75 \%$, and whiskers outside present the minimum and maximum of all the data, ${ }^{*} p<0.05$, Kruskal-Wallis test

crucial for their activation and proliferation [7]. The disturbances in phenotype and proliferation of $\mathrm{CD}^{+} \mathrm{T}$ lymphocytes can be fundamental for deficient cellular and humoral responses in CKD. The question is if these changes depend only on continuous hemodialysis or are strictly connected with CKD progression leading to kidney failure. Therefore, we examined the main parameters of the immune responses of $\mathrm{CD}^{+} \mathrm{T}$ lymphocytes and compared them in hemodialyzed and predialysis patients and healthy controls.

Studies ex vivo showed that the percentage of $\mathrm{CD}^{+}$ lymphocytes and the percentages of their main populations $\mathrm{CD}^{+}$and $\mathrm{CD} 8^{+}$cells are comparable in all examined groups. These observations are very interesting in the context of the data of Borges and colleagues presenting a significant decrease in these particular populations of lymphocytes [11]. However, these parameters were measured immediately after the HD procedure, while our blood samples were collected from each patient before the HD session. This observation indicates that a single contact of PBMC with the dialytic membrane can induce apoptosis of 
$A_{10}$

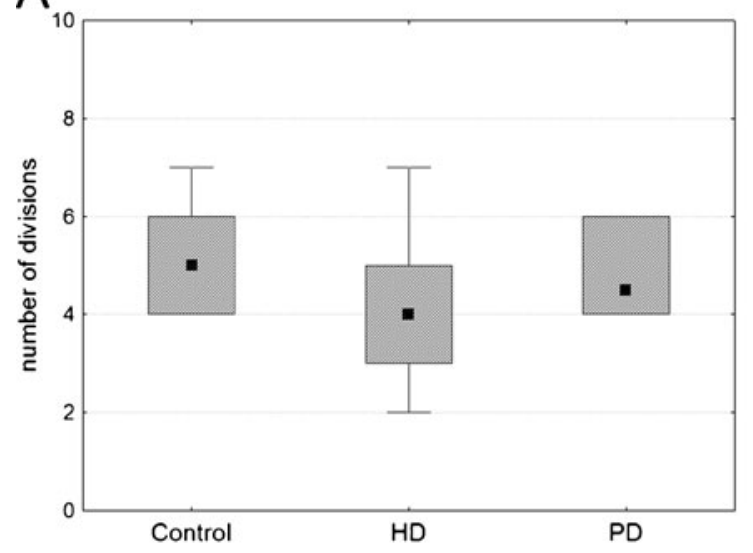

B

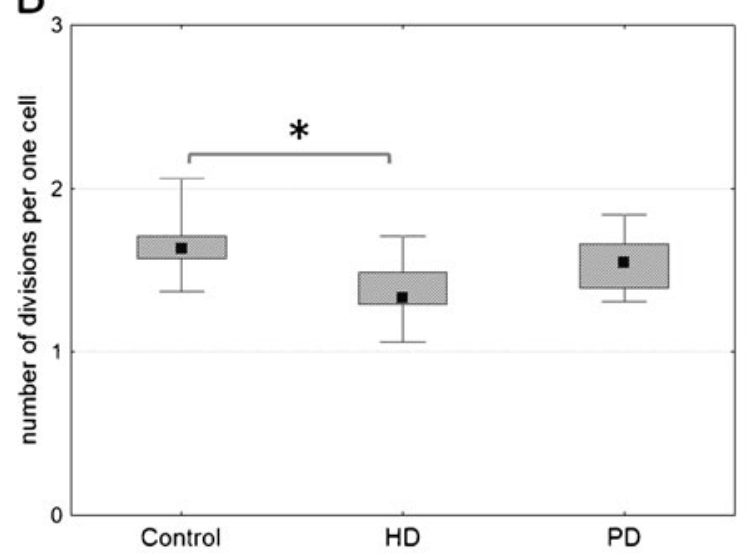

C

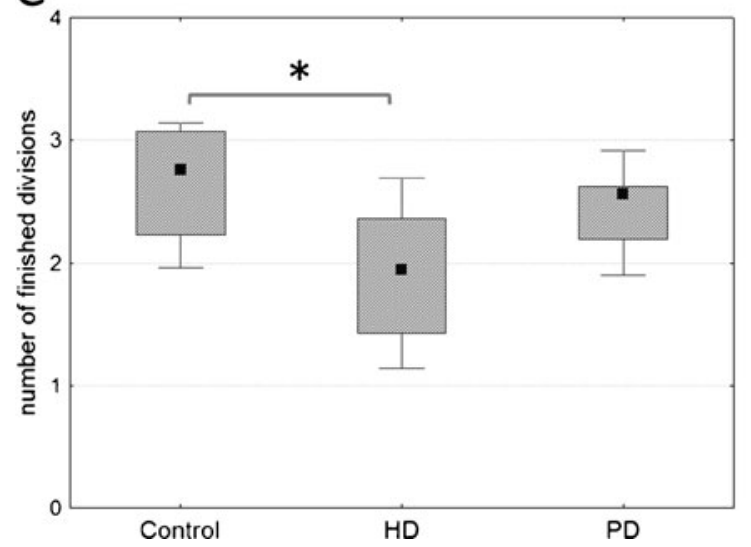

Fig. 8 Comparison of the number of divisions of $\mathrm{CD} 4^{+} \mathrm{CD} 28^{+} \mathrm{T}$ lymphocytes and their correlations with other cell cycle parameters. Graphs present the general number of divisions (a), the number of divisions per one cell (b), and the number of finished divisions (c)

$\mathrm{T}$ lymphocytes. There are studies showing increased apoptosis of $\mathrm{T}$ lymphocytes of CKD patients, mainly Th1 subpopulation, in comparison to healthy controls [15]. According to Alvarez-Lara et al., Th1 lymphocytes of patients presented decreased expression of anti-apoptotic molecule Bcl-2, which made them more susceptible to
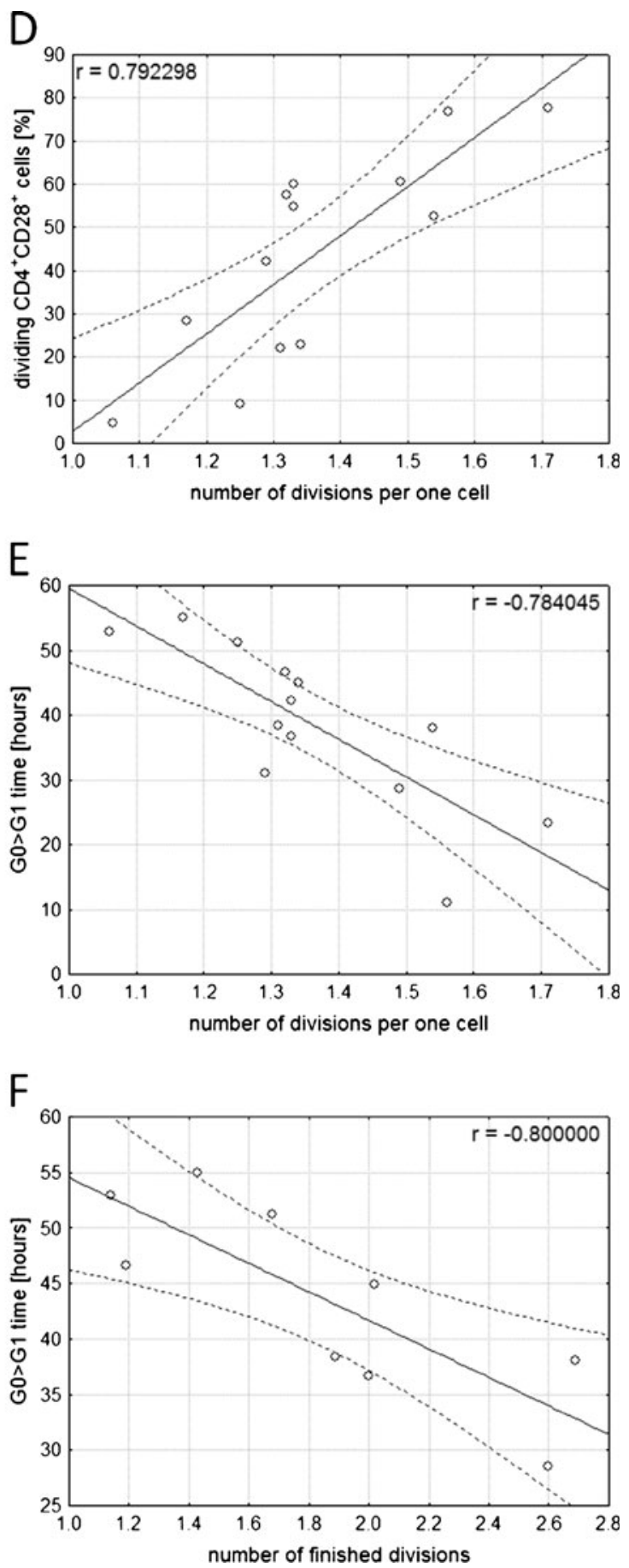

after $72 \mathrm{~h}$ of stimulation with anti-CD3 antibody in examined groups. Midpoints of a-c present medians, boxes present $25-75 \%$, and whiskers outside present the minimum and maximum of all the data, ${ }^{*} p<0.05$, Kruskal-Wallis test. d-f Spearman $R$ correlation

undergo apoptosis, independent of exposure to the dialytic membrane [15]. The mechanisms underlying these results are not known and it is suggested that uremic toxins can act directly on lymphocytes. If this is the case, it is not clear why only Th1 lymphocytes would be more sensitive to these toxins. Anyway, it seems that different results come 

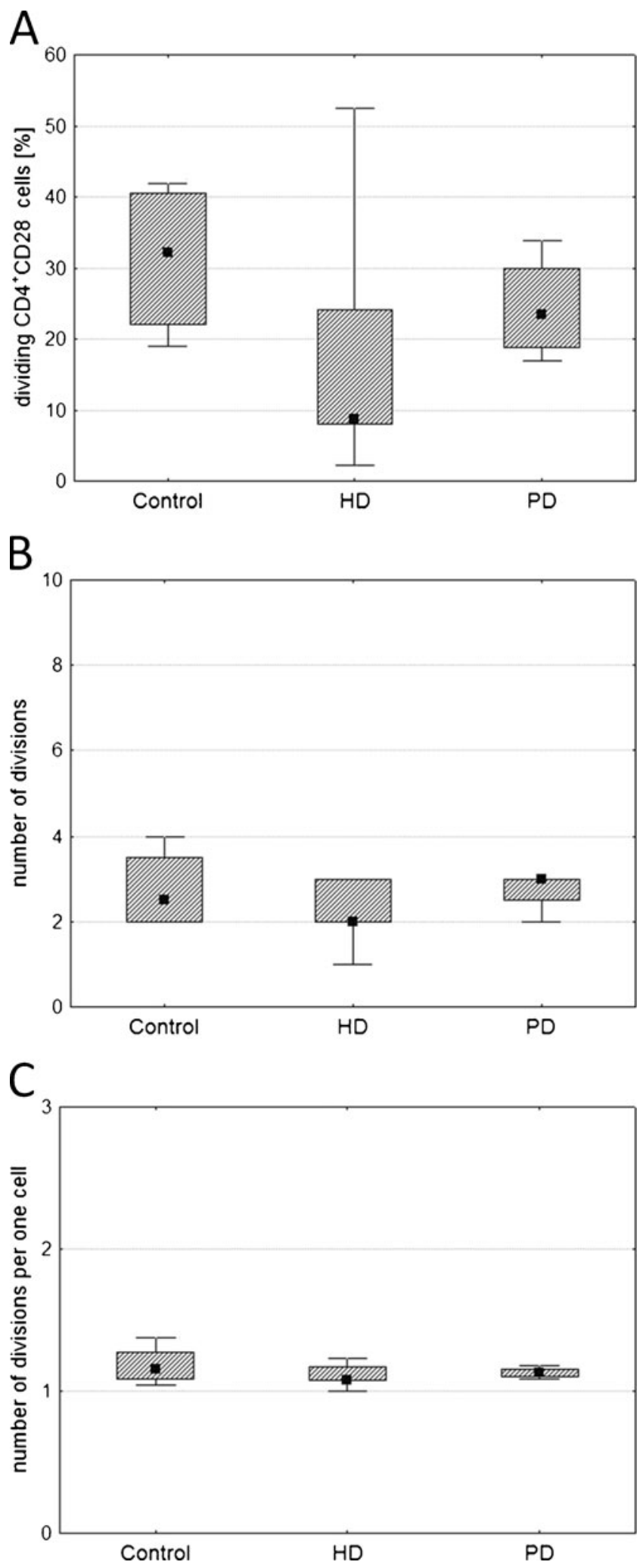

mainly from various methods of preparing blood samples and experimental models used by the authors.

Since there are articles describing the impact of CMV seropositivity on $\mathrm{CD}^{+} \mathrm{T}$ lymphocyte subsets, especially
Fig. 9 Comparison of main cell cycle parameters of $\mathrm{CD} 4^{+} \mathrm{CD} 28^{-} \mathrm{T}$ lymphocytes. Graphs present the percentage of proliferating $\mathrm{CD} 4^{+} \mathrm{CD} 28^{-}$cells (a), the general number of divisions (b), and the number of divisions per one cell (c) after $72 \mathrm{~h}$ of stimulation with antiCD3 antibody in examined groups. Midpoints of a-c present medians, boxes present $25-75 \%$, and whiskers outside present the minimum and maximum of all the data, Kruskal-Wallis test

the increase of the number of circulating $\mathrm{CD} 4^{+} \mathrm{CD} 28^{-}$cells in ESRD patients [16, 17], we also examined the proportions of $\mathrm{CD} 4^{+} \mathrm{CD} 28^{+} / \mathrm{CD} 4^{+} \mathrm{CD} 28^{-}$lymphocytes ex vivo. The percentage of circulating $\mathrm{CD} 4^{+} \mathrm{CD} 28^{+}$lymphocytes in both groups of patients was not decreased in favor of expansion of $\mathrm{CD} 4^{+} \mathrm{CD} 28^{-}$cells as compared to healthy people. No activation-related phenotype of T lymphocytes ex vivo (both early and late) in all examined groups was seen that could indicate that both HD and PD patients did not present an enhanced inflammatory response during the study.

The in vitro experiments showed both significantly lower proportions of $\mathrm{CD} 4^{+} \mathrm{CD} 28^{+}$and $\mathrm{CD} 4^{+} \mathrm{CD} 25^{+}$cells and reduced expression of $\mathrm{CD} 28, \mathrm{CD} 25$, and CD69 antigens only in HD patients, in contrast to PD patients, who had comparable values as the healthy controls. Lower levels of these antigens on $\mathrm{CD}^{+} \mathrm{T}$ lymphocytes of $\mathrm{HD}$ patients strongly indicate that the repeated hemodialysis procedure is the major factor influencing the phenotype of $\mathrm{CD}^{+} \mathrm{T}$ lymphocytes. These changes appear independently of the patients' immunological status ex vivo, as both HD and PD patients presented the proportions of subpopulations of main $\mathrm{CD}^{+} \mathrm{T}$ lymphocytes similar to those observed in healthy controls.

Changes in phenotype of $\mathrm{CD}^{+} \mathrm{T}$ lymphocytes of $\mathrm{HD}$ patients consequently lead to changes in their proliferation parameters. HD patients showed lower percentage of proliferating $\mathrm{CD} 4{ }^{+} \mathrm{CD} 28^{+}$lymphocytes when compared to PD patients and healthy controls. There was no difference between cell cycle duration between all examined groups, but $\mathrm{CD} 4{ }^{+} \mathrm{CD} 28^{+}$lymphocytes of HD patients were characterized by longer time between G0 and G1 phases of cell cycle. We already demonstrated that there is a strict connection between the level of co-stimulatory molecule $\mathrm{CD} 28$ on $\mathrm{CD}^{+} \mathrm{T}$ lymphocytes and the time needed for response to stimulation [18]. This observation was described for healthy people [18] as well as in HD patients not receiving rhEPO [7]. Analysis of the cell cycle also revealed that proliferating $\mathrm{CD} 4{ }^{+} \mathrm{CD} 28^{+} \mathrm{T}$ lymphocytes of $\mathrm{HD}$ patients apart from prolonged $\mathrm{G} 0 \rightarrow \mathrm{G} 1$ time are also characterized by reduced numbers of finished divisions and divisions per one cell in $72 \mathrm{~h}$ of stimulation. Meanwhile, $\mathrm{CD} 4^{+} \mathrm{T}$ lymphocytes of predialysis patients present cell cycle parameters comparable with those of healthy controls.

Changes in cell cycle kinetics did not concern the population of $\mathrm{CD} 4^{+} \mathrm{CD} 28^{-} \mathrm{T}$ lymphocytes in all examined groups, meaning that the main subpopulations changed by 
hemodialysis are $\mathrm{CD} 4{ }^{+} \mathrm{CD} 28^{+} \mathrm{T}$ cells, which play a central role in acquired immune response.

These observations indicate that repeated hemodialysis procedure causes negative changes in the phenotype of $\mathrm{CD}^{+} \mathrm{T}$ lymphocytes of CKD patients. We have demonstrated similar results in a previous article paying attention to the immunomodulatory effects of rhEPO treatment in these patients [7]. Our observations showed that rhEPO administration to HD patients positively influences the levels of crucial surface antigens and proliferation kinetics of these cells [7]. Older studies have also shown that rhEPO treatment causes a decline of TNF- $\alpha$ [19]. High levels of TNF- $\alpha$ could be one of the reasons for lower CD28 expression in HD patients and at the same time indirectly affect the proliferation of $\mathrm{CD} 4^{+} \mathrm{CD} 28^{+} \mathrm{T}$ lymphocytes, since TNF was shown to directly regulate transcription of the $\mathrm{CD} 28$ gene [20] and also influence the CD28 expression on $\mathrm{CD}^{+}{ }^{+} \mathrm{T}$ cells in RA patients treated with anti-TNF [21]. IL-6 is the second proinflammatory cytokine that inhibits differentiation of Th1 lymphocytes [22]. Therefore, one of the depressing effects of repetitive hemodialysis on $\mathrm{T}$ lymphocytes could be dependent on the high levels of these proinflammatory cytokines. On the other hand, blood was collected prior to HD session, before monocytes had any contact with the dialytic membrane. Since there is a predominance of Th1 over Th2 lymphocytes in HD patients [23] in opposition to predialysis patients, who mainly exhibit a Th2 response [24], changes in phenotype of $\mathrm{CD}^{+} \mathrm{T}$ lymphocytes of $\mathrm{HD}$ patients could result from cytokine imbalance.

On the other hand, stress-induced premature senescence (SIPS), a process that involves changes in the function and morphology of cells and is detected among others by telomere shortening, could be another explanation of deficient reactions of $\mathrm{CD}^{+} \mathrm{T}$ lymphocytes of HD patients. Some time ago, Jimenez and colleagues presented the theory of SIPS in CKD [25]. They found the subpopulation of lymphocytes with short telomeres in CKD patients and noticed that the mean telomere length was significantly decreased in mononuclear cells from HD patients treated with cellulosic membranes when compared with noncellulosic and predialysis patients [25]. Lymphocytes of CKD undergo SIPS and repeated hemodialysis procedure deepens this process. In our study, $\mathrm{CD} 4^{+} \mathrm{T}$ lymphocytes of HD patients present lower CD28 and CD25 expression, another sign of proliferative senescence [16, 26, 27].

\section{Conclusions}

For the moment, the mechanisms underlying deficient reactions of $\mathrm{CD}^{+} \mathrm{T}$ lymphocytes of $\mathrm{HD}$ patients remain an open question, and additional studies are needed to explain these observations. However, disturbances in the activation parameters of $\mathrm{T}$ lymphocytes could result from the presence of uremic toxins and proinflammatory cytokines, or be related to their early proliferative senescence, which is deepened by continuous hemodialysis.

Acknowledgment This work was supported by a Polish Committee for Scientific Research grants P05B 07724 and N N402 214434.

Open Access This article is distributed under the terms of the Creative Commons Attribution Noncommercial License which permits any noncommercial use, distribution, and reproduction in any medium, provided the original author(s) and source are credited.

\section{References}

1. Johnson CA, Levey AS, Coresh J, Levin A, Lau J, Eknoyan G. Clinical practice guidelines for chronic kidney disease in adults: part I. Definition, disease stages, evaluation, treatment, and risk factors. Am Fam Physician. 2004;70:869-76.

2. Herbelin A, Urena P, Zingraff J, Descamps-Latscha B. Influence of first long-term dialysis on uremia-associated increased basal production of interleukin-1 and tumor necrosis factor $\alpha$ by circulating monocytes. Nephrol Dial Transplant. 1991;6:349-57.

3. Cavaillon JM, Poignet JL, Fitting C, Delons S. Serum of interleukin-6 in long-term hemodialysis patients. Nephron. 1991;60:307-13.

4. Ueki Y, Nagata M, Miyake S, Tominaga Y. Lymphocytes subsets in hemodialysis patients treated with recombinant human erythropoietin. J Clin Immunol. 1993;13:279-87.

5. Morra L, Ponassi GA, Gurreri G, Moccia F, Mela GS, Bessone G. $\mathrm{T}$ lymphocyte subsets in chronic uremic patients treated with maintenance hemodialysis. Biomed Pharmacother. 1990;44:53-6.

6. Kurz P, Kohler H, Meuer S, Hutteroth T, Meyer zum Buschenfelde $\mathrm{KH}$. Impaired cellular responses in chronic renal failure: evidence for a T cell defect. Kidney Int. 1986;29:1209-14.

7. Lisowska KA, Debska-Slizien A, Radzka M, Witkowski JM, Rutkowski B, Bryl E. Recombinant human erythropoietin treatment of chronic renal failure patients normalizes altered phenotype and proliferation of CD4-positive T lymphocytes. Artif Organs. 2010;34: e77-84.

8. Shapiro VS, Truitt K, Imboden JB, Weiss A. CD28 mediates transcriptional upregulation of the interleukin-2 (IL-2) promoter through a composite element containing the CD28RE and NF-IL2B AP-1 sites. Mol Cell Biol. 1997;17:4501-8.

9. Allegra V, Vasile A, Maschio M, Mengozzi G. Immune response after vaccination with recombinant hepatitis surface antigen in maintenance hemodialysis patients and healthy controls. Nephron. 1992;61:339-40.

10. Tetta C, Camussi G, Turello E, Salomone M, Aimo G, Priolo G, et al. Production of cytokines in hemodialysis. Blood Purif. 1990;8:33746.

11. Borges A, Borges M, Fernandes J, Nascimento H, Sameiro-Faria M, Miranda V, et al. Apoptosis of peripheral CD4(+) T-lymphocytes in end-stage renal disease patients under hemodialysis and rhEPO therapies. Ren Fail. 2011;33:138-43.

12. Hasbold J, Gett AV, Rush JS, Deenick E, Avery D, Jun J, et al. Quantitative analysis of lymphocyte differentiation and proliferation in vitro using carboxyfluorescein diacetate succinimidyl ester. Immunol Cell Biol. 1999;77:516-22.

13. Witkowski JM. Advanced application of CFSE for cellular tracking. Curr Protoc Cytom. 2008; Chapter 9: Unit 9.25:1-9. 
14. Chida Y, Sakurai S, Yoshiyama N. The effect of hemodialysis on lymphocytes subset during dialysis. Clin Nephrol. 1986;25:159-64.

15. Alvarez-Lara MA, Carracedo J, Ramirez R, Martin-Malo A, Rodriguez M, Madueno JA, et al. The imbalance in the ratio of Th1 and Th2 helper lymphocytes in uremia is mediated by an increased apoptosis of Th1 subset. Nephrol Dial Transplant. 2004;19:3084-90.

16. Betjes MGH, Weimar W, Litjens NHR. CMV seropositivity determines epoetin dose and hemoglobin levels in patients with CKD. J Am Soc Nephrol. 2009;20:2661-9.

17. Litjens NHR, de Wit E, Betjes MGH. Differential effects of age, cytomegalovirus-seropositivity and end-stage renal disease (ESRD) on circulating T lymphocytes subsets. Immun Ageing. 2011;8:2.

18. Witkowski JM, Bryl E. Paradoxical age-related cell cycle quickening of human $\mathrm{CD}^{+}$lymphocytes: a role for a cyclin D1 and calpain. Exp Gerontol. 2004;39:577-85.

19. Bryl E, Myśliwska J, Dębska-Ślizień A, Rachoń D, Bułło B, Lizakowski $\mathrm{S}$, et al. The influence of recombinant human erythropoietin on tumor necrosis factor $\alpha$ and interleukin-10 production by whole blood cell cultures in hemodialysis patients. Artif Organs. 1998;22:177-81.

20. Bryl E, Vallejo AN, Weyand CM, Goronzy JJ. Down-regulation of CD28 expression by TNF-alpha. J Immunol. 2001;167:3231-8.
21. Bryl E, Vallejo AN, Matteson EL, Witkowski JM, Weyand CM, Goronzy JJ. Modulation of CD28 expression with anti-tumor necrosis factor alpha therapy in rheumatoid arthritis. Arthritis Rheum. 2005;52:2996-3003.

22. Diehl S, Anguita J, Hoffmeyer A, Zapton T, Ihle JN, Fikrig E, et al. Inhibition of Th1 differentiation by IL- 6 is mediated by SOCS1. Immunity. 2000;13:805-15.

23. Sester U, Sester M, Hauk M, Kaul H, Köhler H, Girndt M. T-cell activation follows Th1 rather than Th2 pattern in hemodialysis patients. Nephrol Dial Transplant. 2000;15:1217-23.

24. Libetta C, Rampino T, Dal Canton A. Polarisation of T-helper lymphocytes toward the Th2 phenotype in uremic patients. Am J Kidney Dis. 2001;38:286-95.

25. Jimenez R, Carracedo J, Santamaria R, Soriano S, Madueno JA, Ramirez R, et al. Replicative senescence in patients with chronic kidney failure. Kidney Int. 2005;68:S11-5.

26. Valenzuela HF, Effros RB. Divergent telomerase and CD28 expression patterns in human CD4 and CD8 T cells following repeated encounters with the same antigenic stimulus. Clin Immunol. 2002;105:117-25.

27. Bryl E, Witkowski JM. Decreased proliferative capability of CD4 $(+)$ cells of elderly people is associated with faster loss of activation-related antigens and accumulation of regulatory $\mathrm{T}$ cells. Exp Gerontol. 2004;39:587-95. 